Volume 6, Nomor 1, Tahun 2017, Halaman 19-27

Online di : http://ejournal-s1.undip.ac.id/index.php/jnc

\title{
STUDI KUALITATIF PENGARUH PEMBERIAN KONSELING GIZI TERHADAP PERUBAHAN SIKAP DAN PEMILIHAN MAKAN PADA REMAJA PUTRI OVERWEIGHT
}

\author{
Khory Afifah Iriantika, Ani Margawati*) \\ Program Studi Ilmu Gizi Fakultas Kedokteran Universitas Diponegoro \\ Jln. Prof. H. Soedarto, SH., Semarang, Telp (024) 8453708, Email : gizifk@ undip.ac.id
}

\begin{abstract}
Background : Overweight is a condition causes energy intake are greater then energy expenditure. The factors caused overweight are eating behavior, genetic and physical activity. Alternative approach to solve overweight problem is changing attitudes and food choice through nutrition counseling program. This study aim to determain the influence of nutrition counseling to change attitude and food choice in overweight adolescent.

Method: This research is descriptive with qualitative methods. The qualitative data were gathered by indepth, participant observation, and secondary data. Subject were 11 adolescent girl. Used transtheoritical model for nutrition counseling. Counseling was done 1 time per week for 4 weeks. Subjects were adolescent girl with overweight.

Results : This research found that nutrition counseling can change attitude and food choice behaviors. The behavior food choice in adolescent will be better than before and all subjects are implementing the advice has given by counselor. There is a different between the attitudes and behavior food choice of adolescent before and after nutrition counseling.

Conclusion : Nutrition counseling has a significant effects to changing attitude and behavior food choice on adolescent overweight.
\end{abstract}

Keyword : nutrition counseling, overweight, transtheoritical model, attitude, food choice, adolescent

\begin{abstract}
ABSTRAK
Latar Belakang : Overweight merupakan suatu kondisi yang diakibatkan dari kelebihan asupan energi dibandingkan dengan energi yang digunakan. Faktor penyebab overweight antara lain perilaku makan, genetik, dan aktivitas fisik. Salah satu cara menangani overweigth dengan melakukan perubahan terhadap sikap dan pemilihan makan pada remaja melalui program konseling gizi. Penelitian ini bertujuan untuk mengetahui pengaruh pemberian konseling gizi terhadap perubahan sikap dan pemilihan makan pada remaja putri overweight.

Metode : Penelitian ini merupakan penelitian deskriptif dengan metode kualitatif. Pengumpulan data dilakukan dengan indepth interview, observasi partisipasi, dan data sekunder. Jumlah subyek sebanyak 11 orang. Model konseling yang digunakan adalah transtheoritical model. Konseling dilakukan 1 kali tiap minggu selama 4 minggu. Subjek penelitian adalah remaja dengan status gizi overweight

Hasil : Hasil penelitian menunjukkan terjadi perubahan sikap dan perilaku pemilihan makan setelah dilakukan konseling gizi. Perubahan perilaku pemilihan makan pada remaja menjadi lebih baik, ditunjukkan hampir seluruh responden menerapkan anjuran yang diberikan oleh konselor. Terdapat perbedaan antara sikap dan perilaku pemilihan makan remaja sebelum dan setelah dilakukan konseling gizi.
\end{abstract}

Kesimpulan : Konseling gizi mempengaruhi perubahan sikap dan pemilihan makan pada remaja overweight.

Kata Kunci : konseling gizi, overweight, transtheoritical model, sikap, pemilihan makan, remaja

\section{PENDAHULUAN}

Masa remaja merupakan suatu fase peralihan dari masa kanak-kanak menuju ke masa dewasa. Pada masa remaja terjadi pertumbuhan yang cepat sehingga membutuhkan asupan gizi yang tepat jumlah, jenis makanan, dan frekuensinya. ${ }^{1-3}$ Banyak remaja cenderung melakukan perilaku makan yang salah yaitu asupan zat gizi tidak sesuai dengan kebutuhan atau rekomendasi diet yang dianjurkan. Perilaku makan remaja yang salah dapat menyebabkan munculnya beberapa masalah gizi, salah satunya adalah terjadinya masalah gizi kurang ataupun masalah gizi lebih (overweight dan obesitas). Prevalensi overweight dan obesitas dikalangan remaja meningkat secara drastis di seluruh dunia baik di Negara maju ataupun Negara berkembang yaitu Indonesia. $^{4-6}$

Angka kejadian obesitas pada remaja umur 1219 tahun mengalami peningkatan dari $11 \%$ menjadi $20 \%$ pada 30 tahun terakhir ini. ${ }^{7}$ Data Riskesdas Nasional Tahun 2013 prevalensi gemuk pada remaja umur 13-15 tahun sebanyak $10,8 \%$ yang terdiri dari $8,3 \%$ overweight dan $2,5 \%$ obesitas. Sedangkan remaja umur 16-18 tahun sebanyak 7,3\% yang terdiri dari $5,7 \%$ overweight dan $1,6 \%$ obesitas. Data Riskesdas Jawa Tengah Tahun 2013 remaja umur 1315 tahun sebanyak $7,1 \%$ termasuk dalam kategori overweight dan $2,4 \%$ termasuk dalam kategori obesitas. Sedangkan remaja umur 16-18 tahun sebanyak 5,4\% termasuk dalam kategori overweight dan $1,7 \%$ termasuk dalam kategori obesitas. Data 
Riskesdas Jawa Tengah Tahun 2013 diketahui bahwa prevalensi gemuk remaja umur 13-15 tahun di Kota Semarang sebanyak $11 \%$ overweight dan 4,9\% obesitas. Sedangkan remaja umur 16-18 tahun sebanyak $7,6 \%$ overweight dan $2,7 \%$ obesitas. Prevalensi angka kejadian remaja overweight dan obesitas di Kota Semarang jauh lebih tinggi daripada prevalensi di tingkat provinsi. ${ }^{8,9}$

Kelebihan berat badan terdiri dari overweight dan obesitas yang merupakan akibat dari kelebihan asupan energi (energy intake) dibandingkan dengan energi yang digunakan (energy expenditure). ${ }^{10}$ Overweight pada remaja dapat berpontensi menjadi obesitas bila keadaan tersebut tidak segera ditangani dengan baik. Remaja obesitas berisiko lebih tinggi untuk mengalami masalah kesehatan yang serius, seperti penyakit jantung, stroke, diabetes melitus tipe 2, asma, dan beberapa jenis kanker. Overweight dan obesitas yang dialami remaja dapat mempengaruhi kondisi psikologis dan sosial, seperti risiko peningkatan depresi karena lebih sering ditolak, digoda, dan dikucilkan oleh teman-teman mereka karena berat badan mereka. Obesitas terjadi karena berbagai faktor penyebab antara lain genetik, sikap, pola makan, aktivitas fisik dan faktor-faktor sosial budaya. ${ }^{11,12}$

Overweight pada masa remaja dapat menetap hingga dewasa dan berisiko terjadinya penyakit, sehingga diperlukan upaya penanganan remaja overweight sedini mungkin. Berdasarkan pertimbangan tersebut, remaja overweight dipilih sebagai sampel penelitian dengan tujuan untuk mencegah berkembangnya overweight menjadi obesitas. Penanggulangan kelebihan berat badan dilakukan secara komperhensif, meliputi perubahan sikap, perilaku makan, dan pemilihan makanan dengan pendekatan yang bersifat pendidikan. ${ }^{12}$

Konseling gizi adalah suatu bentuk pendekatan yang digunakan dalam asuhan gizi untuk menolong individu dan keluarga memperoleh pengertian yang lebih baik tentang dirinya serta permasalahan yang dihadapi. Setelah dilakukan proses konseling gizi, diharapkan individu dan keluarga mampu mengambil langkah-langkah yang tepat untuk mengatasi masalah gizi yang dialami termasuk perubahan pola makan serta memecahkan masalah terkait gizi ke arah yang sehat. ${ }^{13}$ Konseling gizi dapat meningkatkan pengetahuan, sikap, dan praktik gizi. ${ }^{14}$ Konseling yang dilakukan diharapkan dapat merubah sikap dan pemilihan makan pada remaja overweight.

Salah satu model konseling yang sering digunakan dalam intervensi untuk merubah perilaku adalah transtheoritical model (TTM). TTM adalah model konseling gizi yang menjelaskan perubahan perilaku individu secara berurutan mulai dari perilaku yang tidak sehat menjadi perilaku yang sehat. TTM ini terdapat beberapa tahapan yaitu precontemplation, contemplation, preparation, action, maintenance, dan relaps. ${ }^{12,13,15}$

Penelitian yang dilakukan di Chicago pada tahun 2006 menunjukkan bahwa konseling dengan menggunakan TTM dapat digunakan untuk merencanakan intervensi diet dalam jangka pendek bagi individu dengan overweight dan obesitas dengan tujuan untuk menurunkan berat badan. ${ }^{16}$ Penelitian lainnya yang dilakukan di Bandung tahun 2007 tentang pengaruh konseling gizi dengan transtheoritical model terbukti efektif dalam merubah perilaku makan atau diet dan aktivitas fisik pada penderita obesitas. ${ }^{17}$ Selain itu, penelitian yang dilakukan di London pada tahun 2014 menunjukkan bahwa penggunaan konseling dengan TTM dapat menurunkan berat badan, merubah kebiasaan pola makan, dan meningkatkan aktivitas fisik. Berdasarkan beberapa penelitian yang telah dilakukan, pemelihan model konseling dengan TTM dirasa tepat untuk merubah sikap dan pemilihan makan pada remaja putri dengan status gizi overweight. ${ }^{12}$ Berdasarkan uraian tersebut peneliti tertarik untuk meneliti pengaruh pemberian konseling gizi terhadap perubahan sikap dan pemilihan makanan pada remaja putri overweight.

\section{METODE}

Penelitian dilaksanakan di SMA Negeri 1 Semarang. Pemilihan lokasi dikarenakan letak SMA Negeri 1 Semarang sangat strategis yaitu berada di pusat kota dan dekat dengan pusat perbelanjaan atau mall dan sebagian besar remaja berasal dari keluarga dengan status sosial ekonomi yang tinggi. Jumlah siswa perempuan di SMA Negeri 1 Semarang yang mengalami overweight ada sebanyak 39 orang, yang terdiri dari kelas $\mathrm{x}$ dan xi. Pengambilan data dilakukan pada bulan Agustus hingga September 2016. Ruang lingkup penelitian termasuk dalam bidang gizi masyarakat. Penelitian ini merupakan penelitian deskriptif dengan pendekatan kualitatif. ${ }^{18}$ Metode kualitatif dapat memudahkan peneliti untuk mendeskripsikan pengaruh konseling gizi dengan transtheoritical model terhadap perubahan sikap dan perilaku remaja overweight.

Populasi target penelitian adalah seluruh remaja overweight di Kota Semarang. Populasi terjangkau dalam penelitian ini yaitu siswa perempuan usia 15-17 tahun dengan status gizi overweight yang merupakan siswa di SMA Negeri 1 Semarang. Sampel dalam penelitian ini adalah siswa perempuan usia 15-17 tahun dengan status gizi overweight dan merupakan siswa dari SMA Negeri 1 Semarang yang memenuhi kriteria inklusi.

Subjek penelitian dipilih dengan metode purposive sampling yang dipilih tidak secara acak 
melainkan didasarkan pada suatu pertimbangan tertentu yang dibuat oleh peneliti sendiri, yaitu sesuai dengan kriteria inklusi yang telah ditetapkan peneliti. ${ }^{19,20}$ Jumlah subjek semula sebanyak 12 orang, tetapi 1 orang subjek mengundurkan diri ditengah penelitian, sehingga total subjek yang diteliti sebanyak 11 orang. Sampel yang didapat telah memenuhi kriteria inklusi, meliputi siswa SMA Negeri 1 Semarang yang berada pada kelas X dan XI, berjenis kelamin perempuan, kelompok remaja putri overweight, serta bersedia menjadi subjek penelitian melalui persetujuan dengan menandatangani informed consent. Kriteria eksklusi adalah subjek absen atau sakit selama penelitian berlangsung dan subjek mengundurkan diri sebelum penelitian selesai. Penelitian ini mengambil subjek yang berjenis kelamin perempuan. Hal ini dikarenakan perempuan lebih cenderung memperhatikan citra tubuh dan lebih tertarik dengan penurunan berat badan dibandingkan dengan remaja laki-laki.

Variabel bebas dalam penelitian ini adalah konseling gizi. Variabel terikat dalam penelitian ini adalah perubahan sikap dan pemilihan makan. Data yang dikumpulkan dalam penelitian yaitu identitas pribadi subjek, hasil pengukuran antropometri, data asupaan makan, dan data pemilihan makan. Data mengenai sikap remaja putri diperoleh melalui pengisian kuesioner (pre dan post), sedangkan data pemilihan makan didapatkan dari hasil wawancara secara mendalam dan menggunakan form Food Frequency Questioner (FFQ).

Pelaksanaan konseling gizi dilakukan di SMA Negeri 1 Semarang dengan bantuan 5 orang asisten peneliti yang terlatih. Wawancara mendalam dilakukan kepada seluruh subjek untuk melihat bagaimana sikap dan kebiasaan pemilihan makan. Penilaian sikap subjek didapatkan melalui kuesioner yang kemudian dikategorikan berdasarkan penilain sikap. Penilaian pemilihan makan subjek didapatkan dari wawancara mendalam dan pengisian $F F Q$ mengenai kebiasan makan subjek 1 bulan terakhir atau sebelum dilakukan proses konseling gizi.

Proses konseling yang diberikan adalah dengan cara melakukan pre-test pada subjek, yaitu dengan cara memberikan kuesioner sikap dan $F F Q$. Hal ini dilakukan untuk mengetahui bagaimana sikap subjek sebelum dilakukan konseling gizi dan untuk mengetahui asupan dan pemilihan makan subjek 1 bulan terakhir. Subjek yang terpilih diberi perlakuan konseling gizi sebanyak 4 kali pertemuan selama 1 bulan dengan waktu \pm 45 menit untuk setiap kali sesi. Setelah selesai dilakukan konseling gizi sebanyak 4 kali, subjek diberikan post-test. Hal ini dilakukan untuk melihat perubahan sikap dan pemilihan makan setelah dilakukan konseling gizi pada remaja putri overweight. Post-test yang diberikan sama seperti saat memberikan pre-test.

Pada pertemuan pertama konseling dilakukan wawancara mendalam dengan subjek mengenai latar belakang keluarga, permasalah mengenai sikap dan bagaimana perilaku keseharian subjek dalam pemilihan makan, sejak kapan permasalahan itu muncul, apakah subjek menyadari terdapat permasalahan, dan usaha apa saja yang sudah dilakukan untuk mengatasi permasalah tersebut. Pertemuan kedua, membahas tentang alasan subjek melakukan perubahan, usaha apa saja yang telah dilakukan untuk mengatasi permasalahan yang ada, dan bagaimana dukungan dari keluarga dan teman tentang perubahan yang dilakukan subjek. Pertemuan ketiga membahas tentang adakah peningkatan dari usaha yang dilakukan, apakah keluarga dan teman tetap mendukung, dan apakah subjek sudah mulai merasa puas terhadap perubahan yang dilakukan. Pertemuan keempat, konselor memberikan motivasi kepada subjek supaya tetap mempertahankan perubahan yang sudah dilakukan atau bahkan meningkatkan perubahan yang ada.

Sikap adalah kesiapan atau kesediaan remaja untuk bertingkah laku atau merespon sesuatu tentang sikap terhadap gizi. Sikap remaja dinilai menggunakan kuesioner yang ditandai dengan menuliskan jawaban sangat setuju (SS), setuju (S), kurang setuju (KS), tidak setuju (TS), dan sangat tidak setuju (STS). Remaja yang menjawab dengan benar pada pernyataan positif diberikan skor yaitu sangat setuju $(\mathrm{SS})=5$; setuju $(\mathrm{S})=4$; kurang setuju $(\mathrm{KS})=3$; tidak setuju $(\mathrm{TS})=2$; sangat tidak setuju $(\mathrm{STS})=1$. Sedangkan peryataan negatif diberikan skor yaitu sangat setuju $(\mathrm{SS})=1$; setuju $(\mathrm{S})=2$; kurang setuju $(\mathrm{KS})=3$; tidak setuju $(\mathrm{TS})=4$; sangat tidak setuju $(\mathrm{STS})=5$. Subjek dikatakan bersikap baik terhadap gizi bila jawaban benar $>80 \%$, bersikap cukup bila jawaban benar $60-80 \%$, dan bersikap kurang bila jawaban benar $<60 \%$. ${ }^{21,22}$

Pemilihan makan adalah perilaku yang ditunjukan responden dalam memilih makanan yang dikonsumsinya, seperti konsumsi makanan tinggi kalori, tinggi lemak, tinggi kolesterol, dan rendah serat. Alat ukur yang digunakan adalah dengan menggunakan cara wawancara secara mendalam terhadap responden dan pengisian Food Frequency Questioner $(F F Q){ }^{23}$

Analisis data dilakukan bersama dengan proses pengumpulan data. Proses analisis data dimulai dengan mengumpulkan seluruh data wawancara, observasi secara langsung, hasil pengisian kuesioner dan $F F Q$, dan catatan lapangan. Selanjutnya dilakukan penilaian kuesioner dan $F F Q$ menggunakan software untuk mengetahui asupan 
subjek dan mengintegrasikan hasil analisis dalam bentuk deskriptif. ${ }^{18,24,25}$

\section{HASIL}

\section{Gambaran Umum Subjek}

Berdasarkan hasil penapisan yang dilakukan pada bulan Agustus di SMA Negeri 1 Semarang terdapat 39 remaja perempuan dengan status gizi overweight. Diantaranya 11 orang yang tergolong overweight memenuhi kriteria inklusi sebagai subjek penelitian. Subjek yang diteliti berusia 15-16 tahun, dengan berat badan $57,5 \mathrm{~kg}-75,5 \mathrm{~kg}$. Tinggi subjek yang diteliti $144,1 \mathrm{~cm}-166,85 \mathrm{~cm}$. Status gizi subjek berdasarkan baku antropometri WHO 2007 dihitung dengan nilai z-score IMT/U adalah 1,03 SD - 1,83 SD dan termasuk dalam kategori overweight.

Pada pertemuan pertama konseling, diketahui terdapat 1 orang yang termasuk dalam tahap precontemplation, 2 orang termasuk dalam tahap contemplation, 5 orang termasuk dalam tahap action, dan 3 orang termasuk dalam tahap maintenance berdasarkan TTM. Subjek yang termasuk dalam tahap precontemplation belum menyadari bahwa dirinya memiliki masalah kesehatan yaitu overweight ataupun tidak menyadari bahwa pemilihan makannya selama ini kurang tepat. Subjek yang termasuk dalam tahap contemplation sudah menyadari bahwa dirinya mengalami masalah kesehatan yaitu overweight dan perilaku pemilihan makan yang salah serta memiliki keinginan untuk melakukan perubahan.

Subjek yang termasuk pada tahap action sudah melakukan perubahan untuk mengatasi permasalah kesehatan yang dialaminya. Beberapa contoh usaha yang dilakukan subjek adalah dengan melakukan diet yang diawasi, diet yang tidak diawasi, puasa, dan melakukan perubahan perilaku seperti pola makan dan olahraga. Perubahan pola makan yang dilakukan adalah dengan cara banyak mengkonsumsi sayur, buah, dan air putih, mengurangi konsumsi makanan dan minuman manis, serta mengurangi konsumsi makanan yang digoreng atau makanan yang tinggi lemak dan tinggi kolesterol. Subjek yang termasuk pada tahap maintenance gagal untuk mempertahankan pola hidupnya yang sehat dikarenakan kurangnya dukungan dan motivasi baik dari keluarga dan lingkungan sekitarnya.

\section{Sikap Terhadap Gizi}

Hasil dari pertemuan pertama konseling adalah untuk mendapatkan data pre-test sebelum dilakukan konseling gizi mengenai sikap terhadap gizi, penyebab permasalahan yang ada pada subjek, latar belakang keluarga subjek, usaha apa saja yang telah dilakukan subjek untuk mengatasi permasalahan yang ada. Hasil pre-test yang telah dilakukan sebelum konseling gizi untuk mengetahui sikap subjek terhadap gizi, didapatkan hasil bahwa 6 orang $(54,5 \%)$ memiliki sikap yang baik terhadap gizi dan 5 orang $(45,5 \%)$ memiliki sikap yang cukup terhadap gizi.

Setelah dilakukan proses konseling gizi sebanyak 4 kali, kemudian dilakukan post-test. Berdasarkan hasil post-test terjadi perubahan yaitu subjek yang memiliki sikap terhadap gizi cukup menjadi baik seluruhnya. Sehingga seluruh subjek yaitu 11 orang $(100 \%)$ pada penelitian ini memiliki sikap yang baik terhadap gizi. Perubahan sikap ini terjadi karena subjek sudah merasa cukup mendapatkan informasi yang dibutuhkan tentang gizi.

\section{Pemilihan Makan}

Berdasarkan hasil wawancara yang telah dilakukan, diketahui bahwa beberapa penyebab terjadinya overweight pada subjek dikarenakan adanya faktor genetik dari orang tua dan pemilihan makan subjek yang salah, seperti konsumsi makanan yang tinggi kalori, tinggi lemak, tinggi kolesterol, dan rendah serat. Pemilihan makan subjek yang salah disebabkan karena orang tua subjek melakukan perilaku tersebut. Di rumah subjek selalu diberikan lauk yang diolah dengan cara digoreng, jarang diberikan sayur dan buah, jenis menu makan yang kurang beragam setiap harinya misalnya selama 1 minggu bisa diberikan ayam goreng secara terus menerus. Permasalahan ini dapat dikarenakan orang tua subjek terlalu sibuk dan orang tua subjek selalu menuruti semua kemauan dari anaknya serta tidak begitu memperdulikan asupan makanan apa saja yang baik untuk anaknya. Orang tua subjek hanya berfikir anaknya mau makan sehingga tidak mudah sakit.

Selain itu, faktor genetik juga mempengaruhi terjadinya overweight pada remaja. Hal ini dibuktikan dengan hasil wawancara terhadap subjek bahwa ratarata orang tua mereka juga mengalami masalah yang sama, yaitu kelebihan berat badan. Terdapat 6 orang tua dari subjek memiliki bentuk tubuh sedang dan 5 orang tua subjek memiliki bentuk tubuh gemuk.

\section{a. Sebelum Konseling Gizi}

Berdasarkan hasil wawancara sebelum dilakukan konseling gizi diketahui terdapat 2 orang subjek yang menyukai makanan yang digoreng. Biasanya subjek dapat menghabiskan 4 buah gorengan dalam sekali makan. 
N1:"...saya sangat menyukai jajanan dan lauk yang digoreng daripada yang dikukus ataupun direbus, setiap hari saya selalu makan gorengan. Gorengan favorit saya itu mendoan dan pisang karamel. Dirumah ibu juga selalu nyedian ayam goreng, ikan goreng, tahu goreng, tempe goreng, dan lain-lain. Tapi tiap hari menunya selalu berbeda sih"

Hasil wawancara sebelum dilakukan konseling gizi terdapat 2 orang subjek yang selalu mengkonsumsi makanan dan minuman manis. Jenis makanan dan minuman manis yang sering dikonsumsi yaitu coklat, cake, permen, es krim, jus buah dengan gula pasir, dan puding. Kedua subjek selalu mengkonsumsi makanan dan minuman manis ini. Salah satu subjek selalu mengkonsumsi es krim setiap harinya.

N6:"...setiap hari saya selalu makan es krim mulai dari saya pulang sekolah hingga saya mau tidur. Mama selalu menyediakan es krim dirumah, eskrim favorit saya itu yang rasa kacang hijau dan coklat. Setiap weekend kami sekeluarga selalu pergi ke cafe es krim. Kami sekeluarga sangat menyukai es krim."

Hasil wawancara sebelum dilakukan konseling gizi terdapat 5 orang subjek yang menyukai makanan yang digoreng dan minuman manis. Setiap harinya mereka selalu mengkonsumsi makanan dan minuman tersebut. Beberapa jenis makanan dan minumannya antara lain, martabak manis, martabak telor, donat, mendoan, pisang goreng, kentang goreng, bakwan, ayam geprek, coklat, es krim, sirup, teh manis, cappucino cincau, dan mocca float.

Hasil wawancara sebelum dilakukan konseling gizi terdapat 2 orang subjek yang menyukai makanan yang digoreng dan minuman manis, tetapi tidak menyukai sayur dan buah. Mereka berasalasan bahwa sayur rasanya tidak enak dan pahit.

N7:"...saya sangat menyukai gorengan dan minuman manis, gorengan favorit saya itu bakwan, pisang goreng, mendoan, ayam geprek. Selain itu saya sangat menyukai coklat, cake, es teh manis, susu kental manis dingin. Saya tidak menyukai sayuran dari kecil, rasanya pahit sih. Setiap ibu menyediakan sayur di piring saya, pasti saya pinggirkan sayurnya."

N8:"...setiap jam istirahat di sekolah saya selalu makan mendoan, bakwan, pisang goreng, pisang karamel, terus saya juga suka makan roti goreng di kantin. Terus pulang sekolah saya suka beli kentang goreng yang jualan dideket rumah saya. Saya dapat menghabiskan 5 buah gorengan sekali makan, setiap saya beli kentang goreng saya selalu membeli sebanyak 2 porsi. Ayah suka sekali membuat teh manis setiap harinya, jadi saya minum teh manis sebanyak 2 gelas besar setiap harinya."

\section{b. $\quad$ Setelah Konseling Gizi}

Setelah dilakukan konseling gizi, perilaku pemilihan makan subjek perlahan mulai sedikit berubah. Hal ini terlihat dari subjek mulai mengurangi konsumsi gorengannya, yang awalnya setiap kali makan dapat menghabiskan 4 buah sekarang menjadi 2 buah. Subjek mengganti camilan dengan mengkonsumsi buah-buahan, seperti apel, jeruk, pepaya, melon, dan mangga.

N5:"...saya udah kurangin makan gorengan loh, sekarang saya setiap kali makan gorengan cuman 2 buah aja, terus setiap weekend saya lari di tri lomba juang, terus saya juga enggak makan kurupuk terus setiap hari, saya coba makan buah." 
Setelah dilakukan konseling gizi, subjek yang awalnya selalu mengkonsumsi makan dan minuman manis mulai mengurangi konsumsinya. Salah satu contohya, saat minum jus buah subjek tidak menambahkan gula pasir, kemudian subjek mulai mengurangi konsumsi es krimnya.

N6:"...saya tetap masih makan es krim sih, soalnya itu sudah menjadi kebiasaan saya, tapi saya cuman makan 1 es krim setiap harinya. Kalo setiap weekend kami sekeluarga masih tetap pergi ke cafe es krim."

Setelah dilakukan konseling gizi, perilaku pemilihan makan subjek perlahan mulai sedikit berubah. Salah satu contohnya adalah subjek mulai mengurangi konsumsi gorengan dari yang awalnya setiap kalo makan dapat menghabiskan 5 buah menjadi 2 buah. Kemudian, biasanya subjek selalu minum teh manis setiap harinya, subjek mulai mengurangi minum teh manis.

Setelah dilakukan konseling gizi, perilaku pemilihan makan subjek perlaha mulai sedikit berubah. Salah satu contohnya adalah subjek mulai mengurangi konsumsi gorengan dan minuman manis. Tapi salah satu subjek tetap tidak menyukai sayur.

N7:"...saya sudah mengurangi makan gorengan dan minuman manis, tapi saya tetap tidak suka makan sayur, kalo makan buah saya masih mau."

N8:"...sekarang saya sudah jarang makan gorengan. Saya perbanyak makan sayuran dan buah. Saya minum teh manis juga sehari sekali, saya sudah 1 minggu ini tidak beli kentang goreng kesukaan saya."

Pemilihan makan merupakan bentuk perilaku dari subjek terhadap jenis makanan apa saja yang dikonsumsinya. Asupan makan subjek mengalami perubahan, hal ini dapat diketahui berdasarkan hasil wawancara yang telah dilakukan dan pengisian FFQ sebelum dan sesudah konseling gizi dilakukan. Berdasarkan hasil perhitungan FFQ diketahui bahwa terjadi penuruan asupan energi, karbohidrat, protein, dan lemak setelah dilakukan proses konseling gizi.

\section{PEMBAHASAN}

Overweight dapat terjadi karena asupan energi (energy intake) yang lebih besar dibandingkan dengan energi yang dikeluarkan atau digunakan (energy expenditure). ${ }^{10,26}$ Prevalensi overweight pada remaja mengalami peningkatan diberbagai negara termasuk di Indonesia. Tingginya angka prevalensi overweight pada remaja disebabkan oleh perubahan gaya hidup, lingkungan, dan genetik. Overweight pada remaja cenderung berlanjut hingga dewasa dan dapat meningkatkan resiko morbiditas penyakit tidak menular atau degeneratif yang disebabkan oleh berbagai perilaku modern. Perilaku yang dimaksud adalah kebiasaan pola makan tinggi kalori, tinggi lemak, tinggi kolesterol, dan rendah serat. ${ }^{27}$

Usia subjek penelitian relatif homogen yaitu berkisar antara 15-16 tahun yang termasuk dalam kategori remaja tengah. ${ }^{28}$ Seluruh subjek penelitian adalah remaja perempuan. Pemilihan subjek berjenis kelamin perempuan dikarenakan remaja perempuan cenderung lebih memperhatikan citra tubuh serta lebih tertarik dengan penurunan berat badan dibandingkan remaja laki-laki. ${ }^{29}$

Salah satu upaya yang dapat dilakukan untuk mencegah berkembangnya overweight menjadi obesitas pada remaja salah satunya dapat dilakukan dengan melakukan konseling gizi. Konseling gizi merupakan serangkaian kegiatan sebagai proses komunikasi dua arah untuk menanamkan dan meningkatkan pengertian, sikap, serta perilaku sehingga membantu klien mengenali dan mengatasi masalah gizi melalui pengaturan makanan dan minuman. Pada penelitian ini dilakukan konseling gizi untuk membantu subjek merubah sikap dan perilaku subjek dalam hal pemilihan makan. Konseling gizi dilakukan dengan bantuan 5 orang asisten peneliti yang terlatih.

Pada penelitian ini subjek yang terpilih dan memenuhi kriteria inklusi sebanyak 11 orang. Subjek yang telah terpilih diberikan konseling sebanyak 4 kali dalam kurun waktu 1 bulan dengan durasi konseling \pm 45 menit setiap pertemuan. Konseling gizi yang dilakukan sebanyak 4 kali ini diharapkan mampu merubah sikap dan perilaku pemilihan makan remaja ke arah yang lebih baik. Hal ini didasarkan pada peneltian sebelumnya, yaitu penelitian oleh Iis Rosita menunjukkan hasil bahwa konseling gizi yang intensif dapat merubah perilaku makan atau diet dan aktivitas fisik pada remaja obesitas dengan menggunakan transtheoritical model pada proses konseling. 
Sebelum dilakukan konseling, subjek diberikan pre-test berupa pengisian kuesioner sikap, FFQ, dan wawancara secara mendalam terlebih dahulu untuk melihat bagaimana sikap subjek sebelum dilakukan proses konseling gizi dan untuk mengetahui bagaimana asupan serta pemilihan makan subjek 1 bulan terakhir. Dari hasil wawancara yang dilakukan diketahui bahwa terdapat 1 orang yang termasuk dalam tahap precontemplation, 2 orang termasuk dalam tahap contemplation, 5 orang termasuk dalam tahap action, dan 3 orang termasuk dalam tahap maintenance berdasarkan TTM. Tahapan tersebut menunjukkan bahwa 10 orang subjek yang diteliti telah melakukan beberapa perubahan pada dirinya seperti melakukan diet, puasa, perubahan pemilihan makan, dan melakukan aktivitas fisik secara rutin. Namun, perubahan yang terjadi belum dapat ditingkatkan atau dipertahankan oleh subjek dikarenakan kurangnya motivasi atau dukungan baik dari keluarga, teman, dan lingkungan. Subjek yang termasuk dalam tahap precontemplation tidak menyadari bahwa dirinya masalah kesehatan yaitu overweight ataupun tidak menyadari bahwa pemilihan makannya selama ini kurang tepat.

Dari hasil pre-test diketahui bahwa subjek yang memiliki sikap dengan kategori baik sebanyak 6 orang $(54,5 \%)$ dan sikap subjek dengan kategori cukup sebanyak 5 orang (45,5\%). Setelah dilakukan konseling gizi dan dilakukan post-test didaptkan hasil bahwa adanya perubahan sikap pada subjek, yaitu sikap subjek dengan kategori cukup sebanyak 5 orang $(45,5 \%)$ menjadi baik seluruhnya yaitu 11 orang $(100 \%)$.

Perubahan sikap terjadi karena remaja telah mendapatkan informasi sesuai dengan kebutuhannya mengenai sikap gizi yang seharusnya. Perubahan ini didapatkan setelah dilakukan proses konseling gizi. Perubahan sikap yang terjadi dikarenakan remaja ingin menurunkan berat badan karena ingin terlihat lebih menarik di depan lawan jenisnya, ingin hidup lebih sehat, dan ingin menurunkan berat badannya agar kepercayaan dirinya meningkat.

Tingkat pengetahuan siswa dalam memilih makanan yang dikonsumsinya berpengaruh terhadap sikap dan perilakunya dalam memilih makanan yang akan dikonsumsi. Semakin baik pengetahuan gizi seseorang maka akan semakin memperhatikan kualitas dan kuantitas makanan yang dikonsumsinya. ${ }^{30}$ Dalam hal ini, pengetahuan dan sikap siswa terhadap gizi dikatakan baik. Namun dalam penerapannya hampir seluruh subjek belum memperhatikan pemilihan makan yang akan dikonsumsinya, baik jenis dan frekuensi makan.

Salah satu penyebab terjadinya overweight adalah adanya perubahan gaya hidup salah satunya adalah pemilihan makan. Pemilihan makan adalah proses seseorang dalam memilih maknan untuk dikonsumsi. Kemampuan dan kekuatan seseorang ikut berperan untuk mengendalikan makanan yang dikonsusmsinya. Pengendalian dalam pemilihan makan disini dapat diartikan kemampuan seseorang dalam memilih makanan dari aspek apapun baik berupa makanan yang sesuai selera maupun makan yang sesuai dengan syarat kesehatan sehingga mengarah kepada pemilihan makanan yang baik. ${ }^{31}$

Pemilihan makan sangat dipengaruhi oleh pengalaman pribadi, hubungan dengan orang-orang terdekatnya seperti orang tua dan juga teman sebayanya, serta budaya dalam keluarga dan lingkungannya. ${ }^{32}$ Kebiasaan makan dari orang tua dan teman sebayanya juga turut mempengaruhi pemilihan makan remaja. Apabila orang tuanya dalam pemilihan makan cukup selektif dan disiplin dengan mementingkan kesehatan, maka anak akan meniru perilaku positif orang tuanya. Perilaku ini dapat mempengaruhi anak dalam memilih makanan yang dikonsumsinya dan tentunya akan berdampak pada status gizinya. Namun, jika orang tuanya memilih mengkonsumsi makan tinggi kalori, tinggi lemak, tinggi kolesterol, dan rendah serat. Maka anak akan meniru perilaku pemilihan makan seperti orang tuanya.

Berdasarkan hasil perhitungan FFQ sebelum dilakukan konseling gizi diketahui bahwa asupan energi rata-rata subjek sebesar 3200 kkal, karbohidrat sebesar 446,7 gram, protein sebesar 109,71 gram, lemak 113,4 gram, dan serat 17,3 gram. Asupan energi, karbohidrat, protein dan lemak yang dikonsumsi subjek lebih tinggi daripada rekomendasi yang telah ditetapkan berdasarkan Angka Kecukupan Gizi (AKG). Sedangkan untuk asupan serat yang dikonsumsi oleh subjek sangat rendah daripada rekomendasi yang telah ditetapkan berdasarkan AKG.

Hasil perhitungan FFQ setelah dilakukan konseling gizi diketahui bahwa asupan energi ratarata subjek sebesar 2474 kkal, karbohidrat sebesar 334 gram, protein sebesar 88,7 gram, lemak 86,8 gram, dan serat 11,1 gram. Asupan energi, karbohidrat, protein dan lemak yang dikonsumsi subjek lebih tinggi daripada rekomendasi yang telah ditetapkan berdasarkan Angka Kecukupan Gizi (AKG). Sedangkan untuk asupan serat yang dikonsumsi oleh subjek sangat rendah daripada rekomendasi yang telah ditetapkan berdasarkan AKG. Penurunan asupan energi, karbohidrat, protein, lemak, dan serat subjek setelah dilakukan proses konseling disebabkan oleh beberapa faktor. Faktor yang berhubungan dengan perilaku pemilihan makan yaitu ketersediaan dan kualitas bahan makanan, biaya yang dibutuhkan untuk mendapatkan bahan makanan, waktu persiapan makanan, rasa dan faktor lain yang 
menyebabkan terjadinya perubahan perilaku pemilihan makan. ${ }^{33}$

Pada penelitian ini didapatkan hasil bahwa pemilihan makan subjek sangat bergantung terhadap jenis makanan yang sering disajikan dirumah. Ibu subjek selalu menghidangkan makanan yang disukai subjek dan tidak begitu memperhatikan bagaimana kandungan gizi dan dampaknya bila terus menerus mengkonsumsi makanan tersebut. Salah satu contohnya adalah beberapa subjek yang selalu mengkonsumsi makanan yang digoreng karena ibu selalu menyediakan makanan yang digoreng. Hal ini menyebabkan subjek terbiasa mengkonsumsi makanan yang digoreng. Selain itu perilaku pemilihan makan ini berdampak terhadap pola makan remaja. Remaja cenderung akan mengkonsumsi makan ini secara terus menerus.

Hasil penelitian ini menjukkan bahwa sebelum dilakukan konseling perilaku pemilihan makan pada remaja kurang tepat, dimana banyak sekalai subjek yang menyukai makanan gorengan, makanan manis, minuman manis, minuman bersoda, makanan cepat saji, dan tidak menyukai sayur ataupun buah. Salah satu cara yang dapat dilakukan untuk mengubah perilaku tersebut dengan cara memberikan informasi dan dukungan kepada remaja agar mau berusaha untuk mengubah perilaku pemilihan makannya. Hal tersebut dapat dilakukan dengan memberikan konseling gizi.

Setelah konseling gizi sebagian besar perilaku pemilihan makan remaja meningkat menjadi lebih baik. Hal ini ditunjukkan subjek mulai mengurangi konsumsi gorengan, makanan manis, minuman manis, minuman bersoda, makanan cepat saji, dan subjek mulai mengkonsumsi banyak sayur dan buah. Konseling gizi yang dilakukan dengan transtheoritical model terbukti dapat mengubah perilaku yang tidak sehat menjadi perilaku yang sehat. ${ }^{13}$ Konseling gizi yang dilakukan secara intensif dapat membantu klien dalam mengubah sikap dan perilaku terkait pemilihan makan pada klien.

\section{KETERBATASAN PENELITIAN}

Keterbatasan penelitian ini adalah jumlah subjek yang terlalu sedikit, yaitu hanya 11 orang subjek, sehingga tidak dimungkinkan dilakukan penelitian dengan metode kuantitatif. Penelitian hanya dilakukan dengan studi kualitatif, sebaiknya untuk hasil penelitian yang lebih baik dilakukan kombinasi dengan studi kuantitatif.

\section{SIMPULAN}

Berdasarkan kajian yang telah dilakukan bahwa banyak faktor yang menjadi penyebab terjadinya overweigth pada remaja, diantaranya karena sikap remaja terhadap gizi dan pemilihan makan remaja yang mengandung tinggi kalori, tinggi lemak, menyukai makan atau minuman yang manis, rendahnya asupan serat yang dikonsumsi, dan aktivitas fisik. Konseling gizi merupakan salah satu upaya untuk mengintervensi remaja yang mengalami overweight melalui pengaturan makan atau diet sesuai dengan kondisi remaja tersebut. Konseling dengan pendekatan transtheoritical model terbukti efektif dalam mengubah sikap dan perilaku pemilihan makan pada remaja overweight.

\section{SARAN}

Perlu kajian lebih mendalam terhadap faktorfaktor lain terkait overweight pada remaja selain dari sikap dan pemilihan makan. Perlu ditambahkan jumlah subjek untuk penelitian selanjutnya dan dilakukan penelitian dengan kombinasi studi kuantitatif dan studi kualitatif.

\section{DAFTAR PUSTAKA}

1. Adriani M, Wirjatmadi B. Peranan Gizi Dalam Siklus Kehidupan. Jakarta: Kencana; 2014.

2. Soetjiningsih. Tumbuh Kembang Remaja dan Permasalahannya. Jakarta: Sagung Seto; 2004.

3. M. Marques, A. Moleres, T. Rendo-Urteaga, S. GomezMartinez, B. Zapatera, P. Romero, et al. Design of the nutritional therapy for overweight and obese Spanish adolescents conducted by registered dieticians; the EVASYON study. Nutr Hosp. 2012; 27(1):165-176.

4. Sulistyoningsih H. Gizi Untuk Kesehatan Ibu dan Anak. Yogyakarta: Graha Ilmu; 2011.

5. Sekhobo JP, Edmunds LS, Reynolds DK, Dalenius K, Sharma A. Trends in prevalence of obesity and overweight among children enrolled in the New York State WIC program, 2002-2007. Public Health Rep 2010; 125: 218-224.

6. Savvas CS, Yiannis AK, Charalampos H, Michael JT. Overweight and obesity prevalence and trends in children and adolescents in Cyprus 2000-2010. Obesity Research \& Clinical Practice. 2014. 8, p 426-434.

7. Gruhl E, Karen AVL. Motivational Interviewing for Adolescents: Behavior Counseling for Diet and Exercise. J for Nurse Practioners. 2014. p 493-496.

8. Badan Penelitian dan Pengembangan Kesehatan. Riset Kesehatan Dasar (Riskesdas 2010). Jakarta: Kementerian Kesehatan Republik Indonesia; 2013.

9. Badan Penelitian dan Pengembangan Kesehatan. Hasil Riskesdas 2013 Provinsi Jawa Tengah. 2013. Available from URL: http://www.dinkesjatengprov.go.id/ Accessed March 28, 2016.

10. Imam AA. Manfaat Isoflavon dalam Produk Kedelai Menanggulangi Diabetes serta Mencegah Obesitas dan Osteoporosis [Skripsi]. Makassar: Universitas Hasanuddin; 2013.

11. Puhl RM LJS. obesity, and the health of the nation's children. Psychol Bull. 2007.

12. Mastellos N, Gunn LH, Felix LM, Car J, Majeed A. Transtheoretical model stages of change for dietary and physical exercise modification in weight loss 
management for overweight and obese adults (Review). The Cochrane Library 2014, Issue 2.

13. PERSAGI. Konseling Gizi. Jakarta: Penebar Plus ${ }^{+}$ (Penebar Swadaya Grup); 2013.

14. Noviati, Susanto JC, Selina H, Mexitalia M. The influence of intensive nutritional counseling in Posyandu toward the growth 4-18 month old children. Paediatrica Indonesian 2006;46:57-63.

15. Prochaska, J. O., Wright, J. A., \& Velicer, W. F. (2008). Evaluating theories of health behavior change: A hierarchy of criteria applied to the Transtheoretical Model. Applied Psychology: An International Review, 57(4), 561-588.

16. Judy Gainey Seals. Integrating the transtheoretical model into the management of overweight and obese adults. 2006. Chicago Heart and Vascular Consultants, Mercy Hospital and Medical Center, Chicago, Illinois. Pg : 63-71.

17. Rosita I, Marheni D, Mutyara K. Konseling Gizi Transtheoritical Model Dalam Mengubah Perilaku Makan Dan Aktivitas Fisik Pada Remaja Overweight Dan Obesitas : Suatu Kajian Literatur (Thesis). Bandung: Universitas Padjajaran; 2007.

18. Utarini A. Metode Penelitian Kualitatif. Yogyakarta: UGM; 2000.

19. Saryono, Anggraeni MD. Metodologi Penelitian Kualitatif dalam Bidang Kesehatan. Yogyakarta: Nuha Medika; 2010.

20. Sarwono J. Metode Penelitian Kualitatif \& Kualitatif. Edisi ke-1. Bandung: Graha Ilmu; 2006.

21. Azwar S. Sikap Manusia Teori dan Pengukurannya Edisi ke-2. Yogyakarta: Pustaka Belajar; 2003.

22. Madanijah S. Pendidikan Gizi. Dalam Baliwati YF, Khomsan A, Dwiriani CM. Pengantar Pangan dan Gizi. Jakarta: Penebar Swadaya; 2004.p.115;8.

23. Suharsimi A. Prosedur Penelitian Suatu Pendekatan Praktek; Jakarta: Rineka Cipta. 2002.

24. Sugiyono. Memahami Penelitian Kualitatif. Edisi ke-4. Bandung: Alfabeta; 2008.

25. Moleong LJ. Metodologi Penelitian Kualitatif. Bandung: Remaja Rosdakarya; 2010.

26. Nelms M, Sucher KP, Lacey K, Roth SL. Nutrition Therapy and Pathophysiology. Ed 2nd USA: Wadsworth Cengage Learning; 2010.

27. Mahan LK, Stump SE, and Raymond JL. Karuse's Food adn The Nutrition Care Process Thirteenth Eiditon. USA : Elesevier; 2012.

28. Brwon JE, Isaacs JS, Krinke UB, Lechtenberg E, Murtaugh MA, Sharbaugh C, et al. Nutrition Through the Life Cycle. USA: Wadsworth. 2011.

29. Jacqueline AV, Diane CM, Barbara JR, Terryl JH. Methods for calculating dietary energy density in a nationally representative sample. Procedia Food Science 2 (2013) : 68-74.

30. Azrimaidaliza, Idral Punakarya. 2011. Faktor-faktor yang mempengaruhi pemilihan makan pada remaja di Kota Padang Sumatera Barat tahun 2008. Jurnal Kesehatan Masyarakat Volume 6 nomor 1. Agustus. 2011.

31. Gibney, Michael J, et al. 2009. Gizi Kesehatan Masyarakat. Jakarta : EGC Kedokteran.
32. Susanto. Gizi dan Kesehatan. Malang: Bayu Media. 2006.

33. Madruga SW, Araújo CL, Bertoldi AD. Frequency of fiber-rich food intake and associated factors in a Southern Brazilian population. Cad. Saúde Pública, Rio de Janeiro, 2009 25(10):2249-2259. 